\title{
CYP2C19 wt Allele
}

National Cancer Institute

\section{Source}

National Cancer Institute. CYP2C19 wt Allele. NCI Thesaurus. Code C52358.

Human CYP2C19 wild-type allele is located within 10q24.1-q24.3 and is approximately 90 $\mathrm{kb}$ in length. This allele, which encodes cytochrome P450 2C19 protein, is involved in the metabolism of drugs and xenobiotics. Several allelic variants of the CYP2C19 gene contribute to the poor metabolizer phenotype. Conversely, other allelic variants of this gene contribute to the rapid metabolizer phenotype. 